\title{
Detection of Plant Viruses in Some Ornamental Plants That Act as Alternate Hosts
}

\author{
M. R. Ara ${ }^{1 *}$, M. M. H. Masud ${ }^{2}$ and A. M. Akanda $^{3}$ \\ ${ }^{1}$ Bangladesh Agricultural Development Corporation, Dhaka, Bangladesh \\ ${ }^{2}$ Gouripur Munshi Fazlur Rahman Govt. College, Doudkandi, Comilla, Bangladesh \\ ${ }^{3}$ Dept. of Plant Pathology, Bangabandhu Sheikh Mujbur Rahman Agricultural University, Gazipur- \\ 1706, Bangladesh
}

*Corresponding author and Email: bithi.treno@gmail.com

Received: 4 January 2012 Accepted: 15 November 2012

\begin{abstract}
A study was conducted at the Bangabandhu Sheikh Mujibur Rahman Agricultural University (BSMRAU), Salna, Gazipur to detect virus infecting ornamental plants. Enzyme-linked Immunosorbant Assay (ELISA) and symptomalogy were used for detection. Five viruses namely TPVV (Tomato Purple Vein Virus), CMV-Y (Cucumber Mosaic Virus-Y), OYVCMV (Okra Yellow Vein clearing Mosaic Virus), MYMV (Mung bean Yellow Mosaic Virus), TYLCV (Tomato Yellow Leaf Curl Virus) were detected on Tagetes erecta (Marigold), Salvia splendens (Salvia), Dahlia hybrida (Dahlia), Helichrysum bracteatum (Straw flower), Impatiens balsamina (Garden balsam). CMV-Y caused mosaic of Dahlia and Leaf Curl of Marigold. MYMV caused Yellow Mosaic of Dahlia hybrid, while TYLCV caused mosaic of Helichrysum bracteatum. OYVCMV produced leaf chlorosis on Salvia splendens, and chlorotic spots on Impatiens balsamina. TPVV caused purple leaf on Tagetes erecta.
\end{abstract}

\section{Keywords: Virus, ornamental plants, alternate hosts}

\section{Introduction}

In Bangladesh, almost all crops have been reported to be infected by more than one virus causing severe damage to the yields of the crops (Akanda, 1991; Akanda et al., 1991). Most of the plant viruses have weeds or other alternative natural hosts that provide a reservoir of viruses from which the economically important crop plants may become infected (Neeraj and Zaidi, 2008; Mathews and Dodds, 2008). Weeds, ornamental plants and wild plants near crop field seem to be infected with the viruses of cultivable plant species (Sivalingam and Varma, 2007) and play a key role in the development of virus disease epidemics, because the biotrophic nature of plant viruses obviously requires the alternate hosts to continue association of virus-host- vectors association for the sustainability of the viral pathogens in nature in absence of original crop host. All these make the virus disease epidemiology more complex and hazardous as compared to any other diseases (Maramorosch and Harris, 1981). Since the alternate hosts contribute to the infection on crop plants in the field supplying inocula and act as important initial sources of infection from which the viruses spread into or within a crop, identification of initial foci of infection is important to formulate control measures or management practices against the virus diseases (Maramorosch and Harris, 1981).

Research on virus in Bangladesh has started very recently. As a result, the viruses of most crops remain unidentified and such plants may be the 
alternate hosts of many crops of economic importance. Identification of initial source of infection is important for studying the epidemiological aspects of plant viruses and also to formulate control measures the viral diseases (Thresh, 1982). This study was therefore, undertaken to collect the ornamentals showing virus disease like symptoms under natural conditions at BSMRAU campus and to identify the viruses from the collected samples of ornamentals.

\section{Materials and Methods}

The survey was conducted in the Bangabandhu Sheikh Mujibur Rahman Agricultural University (BSMRAU), Salna, Gazipur. The ornamentals plants showing typical virus disease like symptoms as described by Bos (1978) and Holmes (1964) were collected. The well-expanded leaves with distinct symptoms were considered. The samples were taken into polythene bags for each sample. The numbers of infected plants or leaves were counted, the symptoms were noted and the photographs were taken. The investigation was continued for two weeks.

\subsection{Indicator plants test}

Indicator host/test plants were grown in an insect proof net house. The seeds were sown in the plastic tray contained sterilized soils. After germination, the seedlings were transferred to the pots and each pot contained one seedling for each plant species. The plants were maintained with proper irrigation and intercultural management.

The inocula were prepared from the samples and were inoculated into the host and indicator plants. The leaf sample was macerated using buffer in a mortar and pestle. Four different buffers such as $0.02 \mathrm{M}$ sodium phosphate $\mathrm{pH} 7.1$, $0.2 \mathrm{M}$ sodium phosphate buffers $\mathrm{pH} 7.1,0.02 \mathrm{M}$ potassium phosphate buffers $\mathrm{pH} 7.1$ and $0.2 \mathrm{M}$ potassium phosphate buffers $\mathrm{pH} 7.1$ were used separately for each of the samples. The carborandum powder (600 mesh) was dusted on the surface before inoculation. There were 4 replications for each sample. The inoculated plants were observed up to six weeks of inoculation. The expanded cotyledons were used to inoculate in case of Cucurbetaceous plants. The first leaf was inoculated in leguminous plants. In all other cases the expanded leaves were used for inoculation as mentioned by Noordam (1973).

\subsection{Indirect Enzyme-linked Immunosorbant Assay (Indirect ELISA)}

Indirect ELISA as described by Clark and Adams (1977) was employed for detecting the virus infection in some samples. The leaf sample of the ornamental hosts was macerated with 0.5 $\mathrm{M}$ carbonate buffer $\mathrm{pH} 9.6$ of $10 \mathrm{X}$ dilution and the well of micro-titer plate (NuNC) was coated with the extracted sap at the rate of $200 \mathrm{ji} \mathrm{I} /$ well. The plate was incubated overnight at $4{ }^{\circ} \mathrm{C}$ and washed with washing buffer. After washing, 200 ji I /well skim milk was used and incubated at 37 ${ }^{\circ} \mathrm{C}$ for one-hour. The diluted antiserum of CMV$\mathrm{Y}$ at the rate of $200 \mathrm{ji} \mathrm{I} / \mathrm{well}$ was added and the plate was incubated for $37{ }^{\circ} \mathrm{C}$ for 3 hours. After washing, the diluted conjugate (Antirabbit IgG conjugated with Alkaline Phosphatase) was poured into the micro-titer plate well following three hours of incubation at $37{ }^{\circ} \mathrm{C}$. After incubation the plate was thoroughly washed using washing buffer and then substrate (Pnitrophenyl phosphate disodium salt) was added. After addition of substrate the micro titer plate was incubated for 30 minutes at room temperature and subjected to observe yellow color development for the positive reaction. The absorbance value at $405 \mathrm{~nm}$ was measured using a Micro Reader, Bio Red-450. Positive reaction indicated the presence of the virus.

\section{Results and Discussion}

\subsection{Virus disease-like symptoms on five ornamental spices}

Purple color on the leaves and curling of the infected plants were the major symptoms in 
Tagetes erecta (marigold). Leaf rolling, narrowing, dentation and mild yellowing were also developed (Fig. 1. A-D). Salvia splendens (salvia) developed chlorosis. Older leaves showed clear symptoms than that of the younger leaves (Fig. 1. E-F). Yellow mosaic and mosaic symptoms (Fig. 1. G-I) appeared in Dahlia hybrida (Dahlia). Mosaic and mild yellowing (Fig. 1. J) was observed in Helichrysum bracteatum (straw flower). The chlorotic spots (Fig. 1. K) appeared as major symptoms in Impaliens balsamina (garden balsam).

The prevalence of virus disease-like symptoms recorded on the five different ornamental species are presented in Table 1. In all 25\% and $75 \%$ prevalence of purple leaf and leaf curl symptom, respectively, were found to be prevalent in marigold; while $20 \%$ was noted in salvia. In case of Dahlia, $35 \%$ and $62 \%$ yellow mosaics and mosaic, respectively, were recorded. The strawflower produced $55 \%$ mosaic, while garden balsam showed $85 \%$ chlorotic spots under natural condition.

Chlorotic spot of garden balsam had the highest prevalence followed by leaf curl in marigold, mosaic in dahlia and straw flower, yellow mosaic in dahlia, purple leaf in marigold and leaf chlorosis in salvia.

\subsection{Inoculation test of virus disease-like symptoms on five ornamental species}

The results of inoculation test are presented in Table 2. The results demonstrated that all the symptoms except mosaic of dahlia (Dahlia hybrida) and leaf curl of marigold (Tagetes erecta) were mechanically non-inoculated in 25 test or indicator plants among the 42 test plants.

The dahlia mosaic and leaf curl of marigold were found to be mechanically inoculated on test plants. The symptoms so far obtained upon inculcation of dahlia mosaic and leaf curl of marigold are presented in Table 3. Systemic mosaic was produce on 17 test plants among the 42.

In Dahlia hybrida systemic mosaic and curling were produced, while necrotic local lesion was produced in Chenopodium amaranticolor and Gomphrena giobosa. Cucumis sativus produced chlorotic local lesion, which became systemic produced systemic yellow mosaic, while leaf curl was developed in Tagetes erecta. Yellow mosaic symptom was produced on $N$. tabacum cv. Orinico, Cucumis melo, and Cucurbita moschata. The symptom produceed by the dahlia mosaic and leaf curl of marigold on different plants were found to be similar as described by Franki et al. (1979) and Neeraj and Zaidi (2008) for Cucumber mosaic virus (CMV).

Table 1. Prevalence of virus disease like symptoms developed on five ornamental species under natural condition

\begin{tabular}{llcc}
\hline Ornamental Species & Major Symptom & $\begin{array}{c}\text { Healthy } \\
\text { Plants }(\%)\end{array}$ & $\begin{array}{c}\text { Infected Plants } \\
(\%)\end{array}$ \\
\hline Tagetes erecta (Marigold) & 1. Purple leaf & 75 & 25 \\
Salvia splendens (Salvia) & 2. Leaf curl & 25 & 75 \\
Dahlia hybrida (Dahlia) & Leaf chlorosis & 80 & 20 \\
Helichrysum bracteatum (Straw flower) & 1. Yellow mosaic & 65 & 35 \\
Impatiens balsamina (Garden balsam) & Mosaic & 38 & 62 \\
& Chlorotic spots & 45 & 55 \\
& & 15 & 85 \\
\hline
\end{tabular}




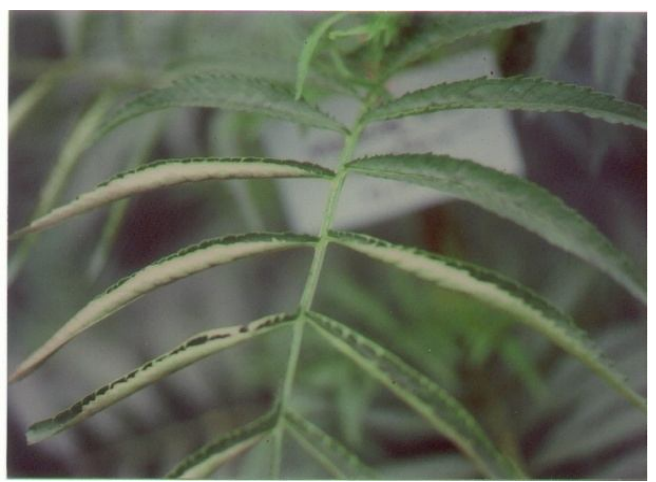

Fig.1.A. Purpling and leaf rolling in Tagetes erecta

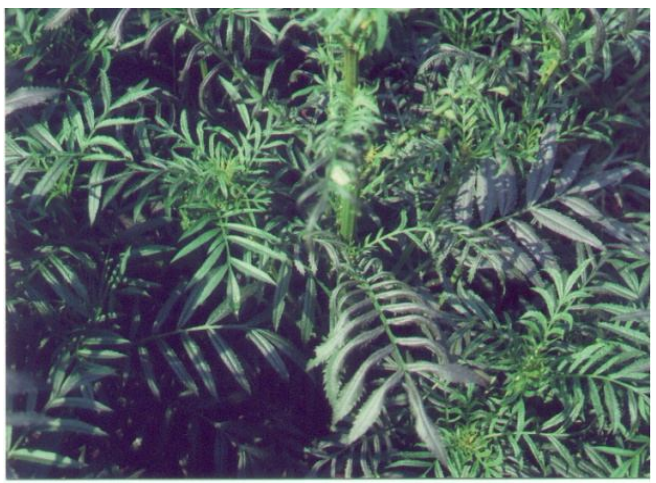

Fig.1.C. Dentation and leaf curl in T. erecta

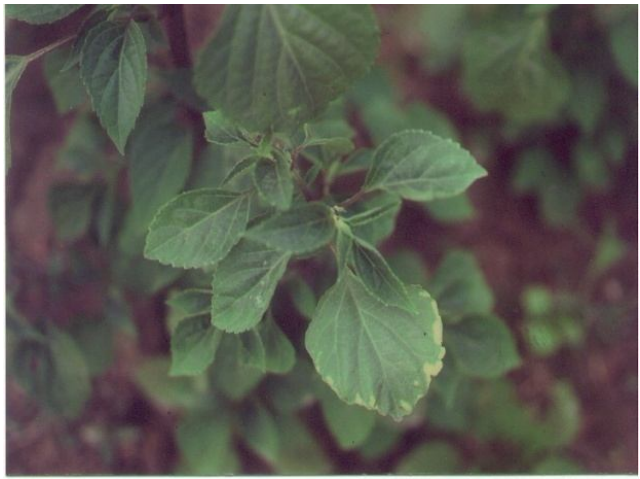

Fig.1.E. Leaf chlorosis in Salvia splendens

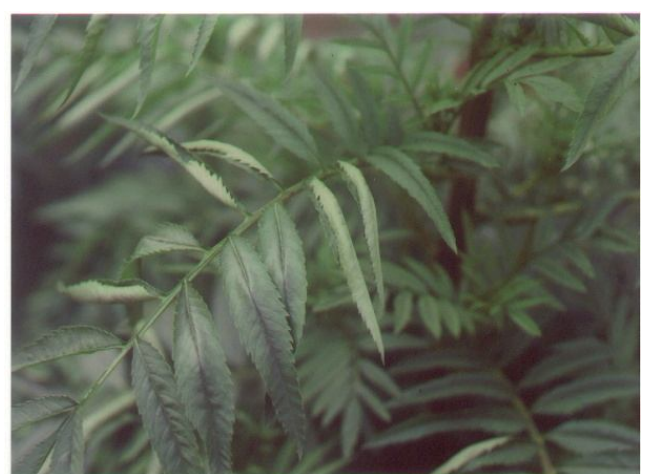

Fig.1.B. Leaf roll in T. erecta

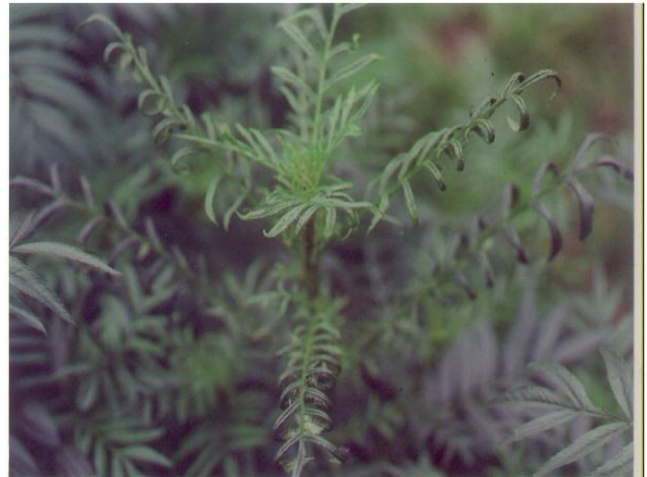

Fig.1.D. Leaf curl in T. erecta

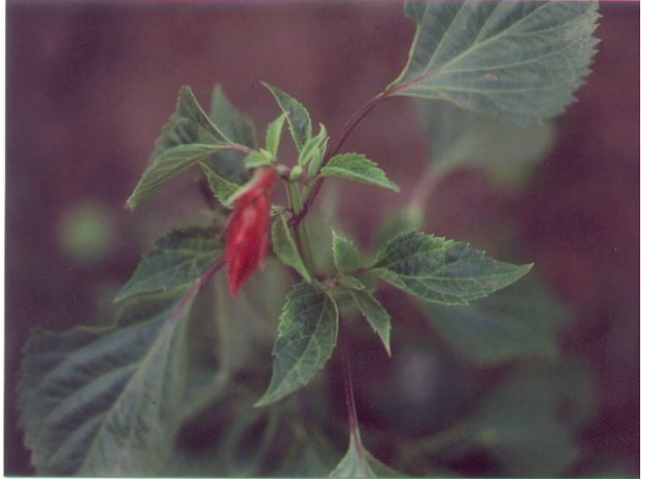

Fig.1.F. Leaf chlorosis in S. splendens 


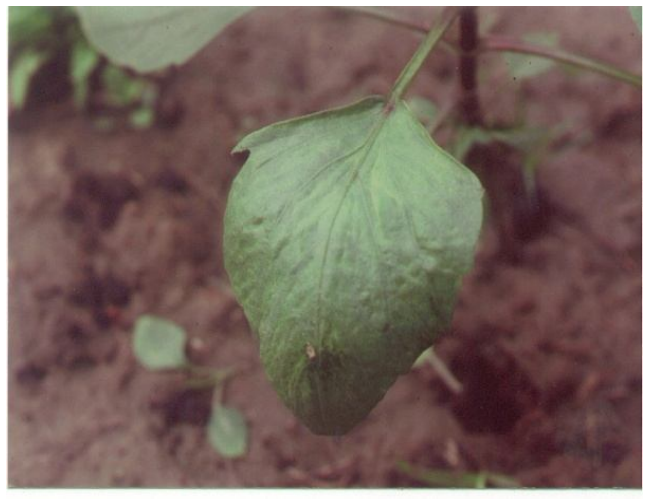

Fig.1.G. Mosaic in Dahlia hybrida

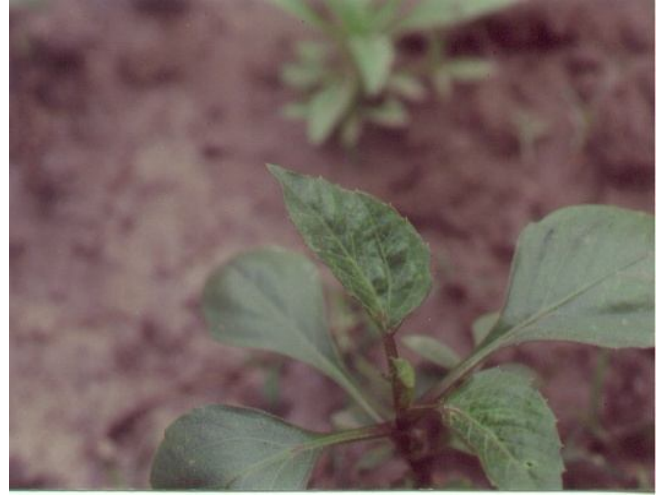

Fig.1.H. Mosaic in Dahlia hybrida

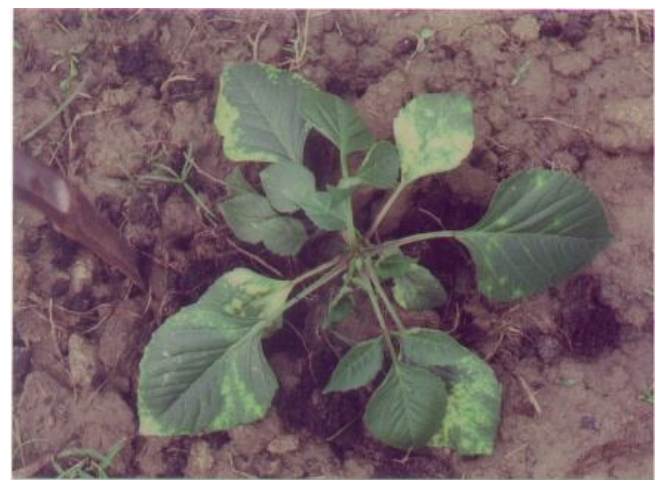

Fig.1.I. Yellow mosaic in Dahlia hybrid

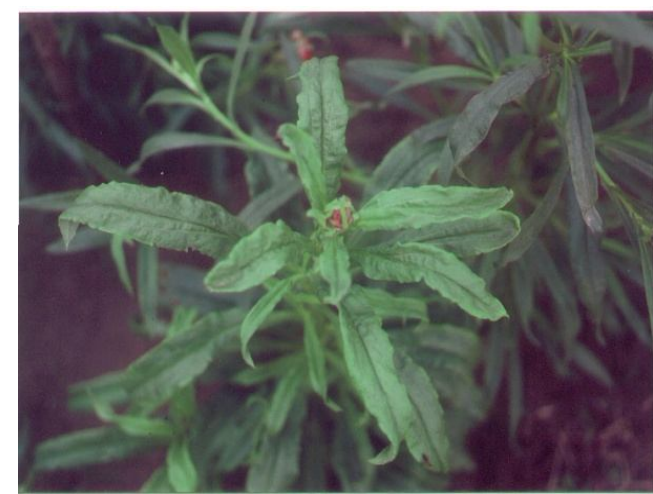

Fig.1.J. Mosaic in Helichrysum bracteatum

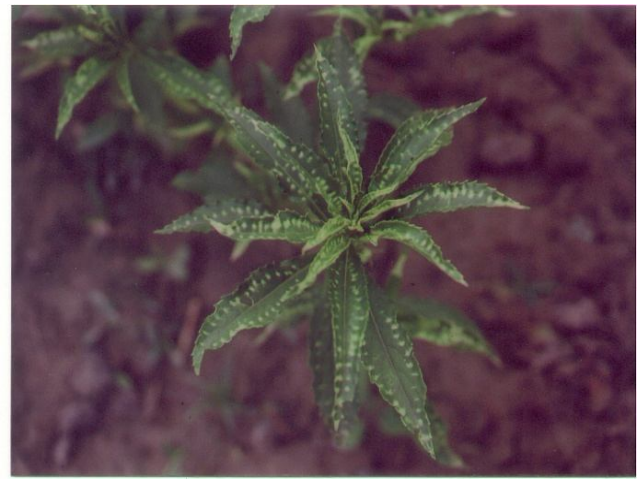

Fig.1.K. Chlorotic spot in Impatiens balsamina 
Table 2. Reaction of inocula (plant virus) on indicator plants except mosaic of dahlia and leaf curl of marigold

\begin{tabular}{|c|c|c|c|}
\hline \multirow{2}{*}{ SL. No. } & \multirow{2}{*}{ Indicator/Test Plants Inoculated } & \multicolumn{2}{|c|}{ Reaction } \\
\hline & & Symptoms Developed & Response \\
\hline 1 & Datura metel & None & - \\
\hline 2 & D. stramonium & , & - \\
\hline 3 & Nicotiana tabacum cv. Xanthi & , & - \\
\hline 4 & N. rustica v. Xovntyl & , & - \\
\hline 5 & Salanum torvum & , & - \\
\hline 6 & Petunia hybrida & , & - \\
\hline 7 & Physatis heterophyila & , & - \\
\hline 8 & Cucumis sativus & , & - \\
\hline 9 & Cucumis melo & , & - \\
\hline 10 & Benincasa hispida & , & - \\
\hline 11 & Citrullus lanatus & , & - \\
\hline 12 & Luffa cylendrica & , & - \\
\hline 13 & L. acutangula & , & - \\
\hline 14 & Lagenaria siceraria & , & - \\
\hline 15 & Trichosanthes anguina & , & - \\
\hline 16 & Ageratum conyzoides & , & - \\
\hline 17 & Blumea lacera & , & - \\
\hline 18 & Helichrysum bracteatum & , & - \\
\hline 19 & Synedrella nodiflora & , & - \\
\hline 20 & Carica papaya & , & - \\
\hline 21 & Salvia splendens & , & - \\
\hline 22 & Impatiens balsamina & , & - \\
\hline 23 & Jussiaea suffruticosa & $"$ & - \\
\hline 24 & Ficus hispida & , & - \\
\hline 25 & Tetragonia expansa &, & - \\
\hline
\end{tabular}

I-ELISA test proved that mosaic symptom of dahlia and leaf curl of marigold reacted positively against the polyclonal antibodies of Cucumber mosaic virus-Y (CMV-Y). All other symptoms were negative in I-ELISA test (Table 4). The results proved that the mosaic symptoms of dahlia and leaf curl of marigold were infected by CMV-Y.

TPVV were identified as a possible cause of Purple leaf symptom of Tagetes erecta (Table 
5). TYLCV was suspected as the cause of mosaic of Helichrysum bracteatum. Leaf chlorosis and chlorotic spots of Salvia splendens and Impatiens balsamina were possibly caused by OYVCMV. The symptoms so far noted on the ornamental plants seemed to be identical to TYLCV, TPVV, MYMV and OYVCMV as described by Green and Kalloo (1994) for TYLCV, Gupta (2000) for TPVV, Green and kirn (1991) and Capoor and
Verma (1950) for OYVCMV in the respective host arid other hosts including weeds. All these Geminivirus (TYLCV, TPVV, MYMV ana OYVCMV) were found to be prevalent in Bangladesh and several studies were conducted on all those viruses at BSMRAU (Gupta, 2000; Begurn, 2002; Alam, 2001 and Chowdhury, 2001; Sivalingam and Varma, 2007).

Table 3. Response of indicator/test plants inoculated with mosaic symptom of dahlia and leaf curl symptom of marigold

\begin{tabular}{|c|c|c|c|}
\hline \multirow{2}{*}{$\begin{array}{l}\text { SL. } \\
\text { No. }\end{array}$} & \multirow{2}{*}{ Indicator/Test Plants Inoculated } & \multicolumn{2}{|c|}{ Reaction } \\
\hline & & Symptoms Developed** & Response* \\
\hline 1 & Nicotiana tabacum cv. NN & smos & + \\
\hline 2 & N. tabacum cv. Samson & smos & + \\
\hline 3 & N. tabacum cv. White barley & smos & + \\
\hline 4 & N. tabacum cv. Bright yellow & smos & + \\
\hline 5 & N. tabacum cv. Virginia gold & smos & + \\
\hline 6 & N. tabacum cv. Orinico & ymos & + \\
\hline 7 & N. ghitinosa & smos & + \\
\hline 8 & Lycopersicon esculentum & smos & + \\
\hline 9 & Physalis floridana & cll, ymos & + \\
\hline 10 & Cucurbita moschata & ymos & + \\
\hline 11 & Dolichos lablab & ymos & + \\
\hline 12 & Phaseolus vulgaris & ymos & + \\
\hline 13 & Pisum sativum & ymos & + \\
\hline 14 & Tagetes erecta & lc & + \\
\hline 15 & Dahlia hybrida & mos, lc & + \\
\hline 16 & Chenopodium amaranticolor & nll & + \\
\hline 17 & Gomphrena globosa & nll & + \\
\hline
\end{tabular}

* ‘-, Negative Response, ‘+, Positive Response

** cll (Chlorotic Local Lesion), ymos (Yellow Mosaic), lc (Leaf curl), mos (Mosaic), nll (Necrotic Local Lesion), smos (Systemic Mosaic) 
Table 4. Response of virus disease like symptoms against antiserum in I-ELIZA

\begin{tabular}{lcc}
\hline Symptoms & Color Developed* & OD \\
\hline Mosaic of Dahlia & + & 0.724 \\
Yellow Mosaic of Dahlia & - & 0.823 \\
Healthy Plant of Dahlia & - & 0.337 \\
Purple Leaf of Marigold & - & 0.748 \\
Leaf curl Marigold & + & 1.027 \\
Healthy Plant of Marigold & - & 0.627 \\
\hline
\end{tabular}

* ‘-, (Negative Response) and ‘+, (Yellow color)

Table 5. Identification of viruses infecting virus disease like symptoms developed on five ornamental species based on symptoms and inoculation test and I-ELISA test

\begin{tabular}{llc}
\hline \multicolumn{1}{c}{ Ornamental Species } & Major Symptom & Causal Virus/Possible causal Virus $^{\mathrm{a}}$ \\
\hline Tagetes erecta (Marigold) & 1.Purple leaf & TPVV \\
Salvia splendens (Salvia) & 2. Leaf curl & CMV-Y \\
& Leaf chlorosis & OYVCMV \\
Dahlia hybrida (Dahlia) & 1.Yellow mosaic & MYMV \\
Helichrysum bracteatum & 2. Mosaic & CMV-Y \\
(Straw flower) & Mosaic & TYLCV \\
Impatiens balsamina & Chlorotic spots & OYVCMV \\
\hline
\end{tabular}

${ }^{\mathrm{a}}$ TPVV(Tomato Purple Vein Virus), CMV-Y(Cucumber Mosaic Virus-Y ), OYVCMV(Okra Yellow Vein clearing Mosaic Virus), MYMV (Mung bean Yellow Mosaic Virus), TYLCV(Tomato Yellow Leaf Curl Virus)

\section{Conclusions}

The mosaics of dahlia and leaf curl of marigold were caused by Cucumber mosaic virus (CMVY) as detected by inoculation test and I-ELISA test. The other four viruses, such as Mungbean yellow mosaic virus (MYMV) for yellow mosaic of Dahlia hybrida, mosaic of Helichrysum bracteatum, leaf chlorosis of Salvia splendens, and purple leaf of Tagetes erecta were identified as possible causal viruses.

\section{References}

Akanda, A. M. 1991. Studies on the virus and mycoplasma diseases of crops in Bangladesh. Ph.D Thesis. Department of Plant Pathology, Kyushu University, Japan $191 \mathrm{p}$.
Akanda, A. M., Tsuno, K. and Wakinoto, S 1991. Serodeagnosis of viruses infecting some crops of Bangladesh. Journal of the Faculty of Agriculture, Kyushu University, Japan, 35 (3-4): 121-129.

Alam, S.M.B. 2001. Prevalence of Mungbean yellow mosaic virus and its effect on growth and yield of Mungbean. MS. Thesis, Department of Plant Pathology, BSMRAU, Gazipur, $77 \mathrm{p}$.

Begum, A. M. 2002. Prevalence and spread of Okra yellow vein clearing mosaic virus (OkYVCMV) in the field and its impact on growth and yield of Okra. MS Thesis. Department of Plant Pathology, BSMRAU Gazipur, $135 \mathrm{p}$.

Bos, L. 1978. Symptoms of virus diseases in Plants. Third edition (Revised). Center for 
Agricultural publishing and Documentation, Wageningen, The Netherlands, $224 \mathrm{p}$.

Capoor S. P. and Verma, P. M 1950. Yellow vein mosaic of Hibiscus esculentus L., Indian Journal of Agricultural Science, 20:217-230 (Appeared in CAB Pest Abstract).

Chowdhury, M. A. K. 2001. A study on MYMV in respect to prevalence, field spread and impact on growth and yield of Mungbean. M. S. Thesis, Department of Plant Pathology, BSMRAU, Gazipur, 81 p.

Clark, M. F. and Adams, A.N. 1977. Characteristics of microplate method of enzyme-linked immunosorbant assay for the detection of plant viruses. Journal of General Virology, 34: 475-483.

Franki, R. I. B., Mossop. D. W. and Haifa, T. 1979. Cucumber mosaic virus. CMI/AAB Descriptions of plant Viruses, No. 213, CMI, Kew, Surry, England, 6 p.

Green , S. K. and Kalloo, G. 1994. Leaf curl and yellowing viruses of pepper and tomato: an overview. Asian Vegetable Research and Development Center, Technical Bulletin No. 21, 51 p.

Green, S. K. and Kim, J. S. 1991. Sources of resistance to viruses of pepper (Capsicum spp.): A catalog. Asian Vegetable Research and Development Center, Technical Bulletin No. 20, 72 p.

Gupta, N. D. 2000. Occurrence of Tomato yellow leaf curl virus (TYLCV) and Tomato purple vein virus (TPVV) and their effect on growth and yield of tomato. M. S. Thesis, Department of Plant Pathology, BSMRAU, Gazipur, 77 p.

Holmes, F. O. 1964. Symptomatology of viral diseases in Plants. In M.K. Corbett 4 H.D. Sisler, ed: Plant Virology, Univ. Fla. Prens Gainesville, Florida, USA, 17-38 pp.

Maramorosch, K, and Harris, K. F. 1981. Plant diseases and vectors, ecology and epidemiology. Academic Press: London, 489 pp.

Mathews, D. M. and Dodds, J. A. 2008. First report of Angelonia flower break virus in Nemesia spp. and other ornamental plants in California. Plant Disease, 92(4): 651.

Neeraj Verma. and Zaidi A. A. 2008 Pelargonium: viral diseases and management. In: Characterization, diagnosis and management of plant viruses (ed.). Houston, USA: Studium Press LLC. Volume-4: grain crops and ornamentals, 245-260 pp.

Noordam, D. 1973. Identification of plant viruses methods and experiments. Center for Agricultural Publishing and Documentation, Weageningen, The Netherlands, $207 \mathrm{p}$.

Sivalingam P. N. and Varma A. 2007. Nontomato natural hosts of tomato infecting begomoviruses in north-western India. Indian Journal of Virology, 18(1): 20-27.

Thresh, J. M. 1982. Groping practices and virus spread. Annual Review of Phytopathology, 20: 193-218. 